\begin{tabular}{|c|c|}
\hline Відомості про автора: & Information about the author: \\
\hline $\begin{array}{l}\text { Циба Юрій Григорович - викладач, Чернівецький } \\
\text { національний університет імені Юрія Федьковича } \\
\text { (Чернівці, Україна) }\end{array}$ & $\begin{array}{l}\text { Tsyba Yurii Hryhorovych - lecturer, Yuriy Fedkovych } \\
\text { Chernivtsi National University (Chernivtsi, Ukraina) }\end{array}$ \\
\hline \multicolumn{2}{|l|}{$\begin{array}{l}\text { e-mail: y.tsyba@chnu.edu.ua } \\
\text { https://orcid.org/0000-0002-5571-2887 }\end{array}$} \\
\hline $\begin{array}{l}\text { Ніколайчук Ольга Петрівна - старший викладач, } \\
\text { Чернівецький національний університет імені } \\
\text { Юрія Федьковича (Чернівці, Україна) }\end{array}$ & $\begin{array}{l}\text { Nikolaichuk Olha Petrivna - lecturer, Yuriy } \\
\text { Fedkovych Chernivtsi National University (Chernivtsi, } \\
\text { Ukraina) }\end{array}$ \\
\hline \multicolumn{2}{|l|}{$\begin{array}{l}\text { e-mail: opnikolajcuk@gmail.com } \\
\text { https://orcid.org/0000-0002-4416-3958 }\end{array}$} \\
\hline $\begin{array}{l}\text { Богданюк Антоніна Миколайвна - кандидат педа- } \\
\text { гогічних наук, Чернівецький національний універ- } \\
\text { ситет імені Юрія Федьковича (Чернівці, Україна) }\end{array}$ & $\begin{array}{l}\text { Bohdaniuk Antonina Mykolaivna - Candidate of } \\
\text { Science (Education), Chernivtsi National University } \\
\text { (Chernivtsi, Ukraina) }\end{array}$ \\
\hline $\begin{array}{l}\text { e-mail: a.bohdanyuk@chnu.edu.ua } \\
\text { https://orcid.org/ 0000-0001-8485-9987 }\end{array}$ & \\
\hline
\end{tabular}

УДК 37.015.3(498):351

doi: 10.15330/fcult.33.114-119

Олександра Цибанюк, Антоніна Богданюк

\title{
ГЕНЕЗИС ТА ОСОБЛИВОСТІ РЕАЛІЗАЦІЇ НАЦІОНАЛЬНОЇ ПРОГРАМИ РУМУНІЇ “ВІДКРИЙ ДЛЯ СЕБЕ ОЙНУ" У ФІЗИЧНОМУ ВИХОВАННІ ШКОЛЯРІВ
}

\begin{abstract}
Мета. Розкрити генезис та особливості реалізації програми Румунії “Відкрий для себе ойну” у фізичному вихованні школярів. Методи. Для реалізачії мети дослідження використано комплекс методів: загальнонаукові (аналіз, синтез, порівняння, узагальнення, систематизація) - для обтрунтування актуальності дослідження, визначення понятійно-категоріального апарату, формулювання висновків; конкретно-наукові (теоретичний аналіз архівних документів, періодичних видань, історико-педагогічної літератури, методичних та програмових матеріалів) - для систематизації та класифікацї історикопедагогічної, методичної літератури; конкретно-історичний - для визначення змісту, методів й форм фізичного виховання за вимогами шкільної програми “Практична спортивна підготовка. Ойна"; проблемно-хронологічний - для з'ясування трансформації та розвитку змісту фізичного виховання на прикладі румунської національної гри - “ойна”. Результат. В статі розглянуто генезис рухливої гри “Ойна”, яка стала основою для створення нового виду спорту в Румунї $і$ започаткування начіональної програми “Відкрий для себе ойну”. В статті визначено, що результатом реформ системи освіти у 1998 році стало визнання “ойни” державною наџіональною грою. Визнано, щуо відродження иього виду спорту стало одним із векторів роботи по збереженню $і$ зміцненню власних національних традицій, зокрема, впровадження “ойни” як повноцінної складової шкільної програми “Практична спортивна підготовка” для 5-12 класів. В статті проаналізовано структуру програми, основні знання, специфічні компетенції для всіх рівнів підготовки та методичні рекомендації щуодо організації тренувального процесу. Висновок. Отже, ідея відновлення та популяризачії державної начіональної спортивної гри “ойна”, реалізувалась планом по розповсюдженню самої гри та ї̈ елементів шляхом введення шкільної програми “Спортивна підготовка. Ойна” циклу “Фізичне виховання і спорт” для 5-12 класів загальноосвітніх шкіл з інтегрованою програмою поглибленого вивчення предметів. Запровадження даної програми стало можливим у зв'язку з налагодженням співпраці між Федерацією “ойни” Румунії та Міністерства освіти, науки та інновачії. Крім того, до передумов відносимо історичну популярність та ступінь розповсюдження гри, а також регламентування організаиї занять, уроків та тренувань на законодавчому рівні.
\end{abstract}

Ключові слова: гра Ойна, генезис, програма, інтегроване навчання, компетенції, учні.

The author of the article considers the prerequisites for the creation of a national program of modern Romania "Discover the oina", describes the traditional Romanian sporting game of the Lapty character as a historical heritage of the people, which was popularized in the country from the XIV century. The article states that the result of reforms in the education system in 1898 was the recognition of the "oina" by the state national 
game. It is recognized that the revival of this sport has become one of the vectors of work for the preservation and strengthening of their own national traditions, education in the young Romanian generation of selfidentification. In particular, one of the ways was the introduction of the "oina" as a full-fledged component of the general school curriculum "Practical Sport Training" for grades 5-12 from the curriculum "Physical Culture and Sport". The article analyzes the structure of the program, the basic knowledge that students need to master after completing their studies, specific competencies for all levels of preparation, methodological findings, designed to design the development of each sports discipline. The content of specific competences programmed specifically for this sport is conditionally divided into five groups: 1) general physical training, 2) technical training, 3) sports performance, 4) psychological training, 5) general culture. The given methodological recommendations to teachers and trainers considering that the structures of integrated and additional sports training were created precisely for the effective selection of athletes of sports of the highest achievements. In the same context, the author defines the types and planning in the integrated sport education, which is referred to in the article.

Key words: game, program, integrated learning, competencies, students.

Постановка проблеми й аналіз результатів останніх досліджень. Модернізація українського соціуму постає як практична потреба сучасного етапу державотворення, як завдання конкурентного входження до європейського і світового соціокультурного простору, ствердження в ньому в якості привабливого, перспективного, прогнозованого, а тому і надійного партнера. Громадська думка та соціальна практика здебільшого ігнорують можливості фізичної культури у вирішенні багатьох важливих соціальноекономічних проблем. Проте, для всіх освітян та фахівців галузі стає очевидним, що нині актуальною є потреба глибокого реформування спеціальної освіти та фізичного виховання підростаючого покоління у відповідності із національно-ідейними цінностями та світовою динамікою. В цьому сенсі актуальною постає проблема вивчення теорії та практики освіти з фізичної культури в країнах Європейського Союзу, оскільки наукове обгрунтування подібної проблематики диктується сучасними тенденціями оптимізації або навіть реформування освітнього процесу.

Мета дослідження - розкрити генезис та особливості реалізації програми Румунії “Відкрий для себе ойну” у фізичному вихованні школярів.

Методи й організація дослідження. Для реалізації мети дослідження використано комплекс методів: загальнонаукові (аналіз, синтез, порівняння, узагальнення, систематизація) - для обгрунтування актуальності дослідження, визначення понятійнокатегоріального апарату, формулювання висновків; конкретно-наукові (теоретичний аналіз архівних документів, періодичних видань, історико-педагогічної літератури, методичних та програмових матеріалів) - для систематизації та класифікації історикопедагогічної, методичної літератури; конкретно-історичний - для визначення змісту, методів й форм фізичного виховання за вимогами шкільної програми "Практична спортивна підготовка. Ойна"; проблемно-хронологічний - для з’ясування трансформації та розвитку змісту фізичного виховання на прикладі румунської національної гри “ойна". Такий комплекс методів забезпечує логічність й цілісність наукового дослідження, дає можливість структурувати, порівнювати, типологізувати досліджувані процеси в їхній динаміці, визначати й обгрунтовувати практичну значущість результатів дослідження.

Результати і дискусія. Ойна (Оina або hoina - рум. мова) - традиційна румунська спортивна гра на кшталт лапти. Історично популярна на теренах румунських земель, гра мала низку назв та варіантів: в Банаті іï називали “лапта з маленьким м'ячом”, в Трансільванії - “довгий м'яч”, в районі Сібіу - “ойна”, на молдовських землях “хойна". Дівчата також грали в гру під назвою "оinita”, подібних до ігор, які були популярні в інших країнах, таких як німецька "Schlagball”, фінська "реsäрallo", "paume” у Франції та “Cluiche Corr” в Ірландії. 
Положення Закону 96/2014 про доповнення до Закону про фізичне виховання i спорт №69/2000, що опублікований в Офіційному Віснику Румунії презентували нову главу “Національна програма "Відкрий для себе ойну". Основною тезою цієї глави стало визнання ойни національним спортом Румунії. Основним інструментом для впровадження національної ідеї стала вище визначена державна програма, яка за законом, складається 3 комплексу дій, метою яких визначено розповсюдження та широке використання цієї гри. Основним реалізатором визнана Федерація Ойни Румунії [1].

Враховуючи статус цієї програми, законом прописана підтримка держави, органів центральної адміністрації, неурядових організацій і органів місцевого самоврядування, зокрема, фінансування. Як зазначено, воно повинно бути забезпечено напряму з державного бюджету, власних доходів Міністерства молоді і спорту та місцевих бюджетів.

Проте, задля появи ідеї такої державної програми була проведена потужна робота в сучасній Румунії де існувала історична практика організації ойни в країні. Уперше, в документальній хрониці, ойна зустрічається у XIV ст., коли у 1364 році під час правління Владіслава I у щоденній хроніці вона описана як гра для проведення дозвілля. Інше документальне свідчення датується 1596 роком, коли італійський науковець Ж.Л. д’Ананія згадує гру в “Універсальній системі Всесвіту” в описі Верхньої Валахії [2].

Повідомлення та згадки про ойну зустрічаються в роботі "Diaetetica" Стефана Матюса в 1762 році, надрукованій в Клужі, у мемуарах священика Ніколае Стойки 3 Haţeg (м. Хацег,Трансільванія, Румунія) 1763 року, в яких автор пригадує години проведені з дітьми у дворі церкви в Timișoara (м. Тімішоаре) за грою.

Ще одним потужним результатом реформування системи освіти 1898 року стала трансформація гри “ойна" з рухливої дитячої гри в національне спортивне дійство. Автор таких змін, Спіру Харет запровадив обов'язкві практичні заняття в школах усіх ступенів: "Ойна може принести нове життя румунській школі, будучи чудовим засобом фізичного виховання, справжнім видом румунської спортивної гри", - сказав Спіру Харет. I вже 9-го травня 1899 року в Бухаресті відбувся перший національний чемпіонат 3 ойни, а 3-го червня 1912 року в румунському “Офіційному Бюлетені” публікуються правила проведення гри, тим самим визнавши ойну на державному рівні. На початку грудня 1912 року в Бухаресті була створена "Федерація румунських спортивних товариств" (ФССР), до складу якої входила також “Комісія Ойни”. Румунська Федерація Ойни була заснована в червні 1932 року.

Одразу після Другої світової війни ойна популяризується державою, організовані і проведені ряд місцевих і національних змагань: Кубок Надії, Кубок регіонів, Кубок Румунії, Національний чемпіонат юнаків і дорослих, Кубок міст, Кубок Села, Чемпіонати університетів, “Динамовіада”, Спартакіада, Кубок Федерації, Чемпіонати закладів освіти тощо.

29 червня 1949 року була створена “Центральна комісія ойни”, яка мала на меті формування методичної основи тренувань в цьому виді спорту, моніторинг виконання правил гри командами і гравцями, контроль за роботою арбітрів та інструкторів, підвищення кваліфікації працівників сфери фізичної культури. Історики фізичної культури визначають період соціалістичної Румунії для ойни як етап розвитку та популярності. Проте, після 1990 року національна румунська гра пережила потужний занепад, що призвело майже до зникнення гри [3].

В сучасній Румунії, повноцінному учаснику Свропейського союзу, прикладають максимальні зусилля по збереженню і зміцненню власних національних традицій, вихованню у молодого покоління самоідентифікації. Зокрема, з ініціативи румунської федерації ойни та при підтримці Міністерства освіти, науки та інновацій запущено спільний план по відродженню цього виду спорту. Одним із векторів реалізації цього 
плану стало впровадження ойни як повноцінної складової загальної шкільної програми "Практична спортивна підготовка" для 5-12 класів [4].

Даний предмет забезпечений навчальною шкільною програмою по 51 виду спорту, а ойна є одним 3 них. Програмові вимоги передбачені для трьох рівнів підготовки: початкового навчання, підвищення спортивної майстерності і спортсменів вищих досягнень.

Навчальні програми для кожного виду спорту мають наступну структуру:

$\checkmark$ вступ, в якому визначено роль предмету у національному навчальному плані;

$\checkmark$ основні знання, якими мають оволодіти учні по завершенні навчання;

$\checkmark$ специфічні знання для всіх рівнів підготовки;

$\checkmark$ методичні висновки, розроблені для проектування розвитку кожної спортивної дисципліни.

До основних компетенцій, визначених програмою, відносяться: використання фахової мови; розвиток основних рухових вмінь і навиків відповідно віку, статі і рівня підготовки; адекватна поведінка, базована на засадах "fair-play"; самооцінка фізичного, психологічного, техніко-тактичного та теоретичного потенціалу на тренуваннях і змаганнях; демонстрація позитивного ставлення до здорового способу життя та фізичної культури.

Головним завданням "Практичної спортивної підготовки" визначені розвиток психофізичних якостей та формування здатності учнів використовувати їх з метою досягнення максимального рівня в спортивній змагальній діяльності на фоні формування оптимального стану здоров'я, гармонійного фізичного розвитку і здатності адаптуватися до найрізноманітніших факторів довкілля (фізичних, хімічних, біологічних, соціальних) [4].

Розглянемо зміст специфічних компетенцій, які є важливими в цьому виді спортивної діяльності. Їх умовно можна поділити на п'ять груп: 1) загально-фізична підготовка, 2) технічна підготовка, 3) спортивна продуктивність, 4) психологічна підготовка, 5) загальна культура.

Сомато-функціональні показники як перша 3 компетенцій передбачають контроль показників росту, ваги, частоти серцевих скорочень, екскурсії грудної клітки, ЖЕЛ, м'язової сили правої-лівої кисті як основних, так і специфічних - об'єму талії, статичної сили всіх груп м'язів, слухової, зорової і кінетичної чутливості тощо. Крім того, враховується як ступінь розвитку базових фізичних якостей (швидкісних здібностей, м'язової сили, спритності, витривалості), так і специфічних: швидкості - реакції на видимі подразники; - виконання; - повторення; - переміщення; сили кидання. Важливими є також динамічна рівновага, орієнтація у просторі і часі. На етапі початкової підготовки, на думку авторів програми, найвагомішими повинні стати методи і засоби розвитку максимальної вибухової та статичної сили головних груп м'язів; швидкості реакції, витривалості до аеробних і анаеробно-аеробних фізичних навантажень; а також спритності, рухливості і гнучкості.

До базових технічних компетенцій програма відносить основну стійку гравця, утримання м'яча, прийом-передача на маленькі відстані, подача, прискорення по “коридору”. До специфічних, оволодіння якими, за програмою, повинно проводитись індивідуально, належать кидання в ціль 3 прогресивно зростаючих відстаней, кидання i прийом м'яча в різних позах і напрямках.

Специфічні тактичні дії в атаці і захисті, що вивчаються на початковому етапі включають в себе розміщення гравців на ігровому майданчику; завдання гравців під час передач; бокові паси, короткі і довгі прийоми і передачі. До компетенцій індивідуального захисту віднесено теоретичні знання про обов'язковість підготовчої частини "розминки" та специфіку відновлення. 
Спортивна продуктивність або результативність юного спортсмена розглядається як вміння визначати фактори, які обумовлюють тренування, причини, які знижують продуктивність; аналізувати власні результати та зусилля; здійснювати самохарактеристику. I, відповідно, у спортсмена даного рівня необхідно виховувати такі риси, як стриманість і наполегливість, концентрацію, ініціативу та сміливість, відповідальність та уяву. Ігрова діяльність вимагає також усунення боязні супротивника та формування навичок співпраці і взаємної допомоги.

Важливими знаннями для спортсмена повинні стати правила гри, регламент змагань, можливі помилки арбітрів, часові обмеження, а також правила поведінки під час змагань, критичні та нестандартні ситуації тощо.

Серед загальнокультурних компетенцій визначені такі: обов'язкове опанування особливостями національної культури, духовно-моральні основи людства і окремих народів, володіння ефективними способами організації дозвілля.

Ще однією складовою кожної програми стали методичні рекомендації щодо ефективної реалізації програми. Наведемо основні з них:

- оптимальне використання матеріальної бази і фінансових ресурсів;

- відповідність засобів і методів віку, статі і рівню підготовки учнів;

- оприлюднення змісту, вимог і критеріїв оцінювання учнів, які будуть застосовані;

- виключення із відносин педагог-учень будь-якої форми вербальної або фізичної агресії;

- розуміння спортивного тренування, як процесу постійної адаптації до фізичного навантаження, його тривалість, частота та інтенсивність, а також складність;

- забезпечення безперервності процесу спортивної підготовки впродовж всього року у інтегрованому і додатковому спортивному навчанні;

- відповідальність вчителя-тренера у визначенні спеціалізації спортсмена 3 відповідної дисципліни або його місця в команді, з метою забезпечення максимально можливих результатів;

- забезпечення оптимальної кількості змагань для груп кожного рівня 3 метою систематичної й різностороньої підготовки.

Оскільки структури інтегрованого і додаткового спортивного навчання були створені саме для ефективного відбору здібних до спорту вищих досягнень методичні пропозиції, представлені вище, доповнені серією аспектів, а саме:

- організація відбору здібних учнів шляхом спостереження і об'єктивної оцінки, опираючись на модельні характеристики даної спортивної дисципліни та темперамент;

- забезпечити постійний багатоетапний відбір, спираючись на термін для переходу в групу вищого рівня, психологічний і фізіологічний вік, результати змагань;

- використання актуальних прийомів техніко-тактичної підготовки;

- індивідуальний підхід до спортивної підготовки для учнів 3 нетиповими для віку характеристиками: росту, довжини кінцівок тощо, але дуже ефективними для даної спортивної дисципліни;

- прогресивне використання засобів відновлення по мірі збільшення навантаження та участі у змаганнях;

- забезпечення систематичного медико-спортивного контролю;

- матеріальна підтримка (харчування, сучасне спорядження) учнів, які мають високі спортивні досягнення.

Педагогічне проектування в інтегрованому спортивному навчанні здійснюється у формі 1) річного перспективного плану; 2) календарного планування на семестр (для початківців); 3) планування підготовки по різних етапах, 4) багаторічний перспектив- 
ний план, 5) план індивідуальної підготовки учнів (для груп підвищення спортивної майстерності і груп спорту вищих досягнень).

\section{Висновок}

Отже, ідея відновлення та популяризації державної національної спортивної гри “Ойна”, реалізувалась планом по розповсюдженню самої гри та іiї елементів шляхом введення у шкільну програму “Спортивна підготовка. Ойна” циклу “Фізичне виховання і спорт” для 5-12 класів закладів середньої освіти з інтегрованою програмою поглибленого вивчення предметів. Запровадження даної програми стало можливим у зв'язку з налагодженням співпраці між Федерацією “Ойни” Румунії та Міністерства освіти, науки та інновації.

Крім того, до передумов реалізації цієї програми необхідно віднести історичну популярність та ступінь розповсюдження гри в Румунії, а також регламентування організації занять, уроків та тренувань на законодавчому рівні.

1. Legea nr. 69/2000, legea educatiei fizice si sportului, consolidata 2009. Monitorul Oficial. Partea I. nr. 200. 9 mai 2000.

2. Nicolae Postolache: Fascinația oinei jocul românilor de pretutindeni, Editura Profexim, București, 2009.

3. Redescoperiți și învățaţi sportul nostru național oina. Available from: http://froina.ro/istoric/istoria-jocului.

4. Programe școlare. Pregătire sportivă practică (incepători / avansaţi / perfomanţă). Oina. Anexa nr.2.26 la Ordinul ministrului educaţiei, cercetării și inovării nr.5098/09.09.2009. București, 2009. 15 p. P. 2.

Цитування на цю статтю:

Цибанюк ОO, Богданюк АМ. Генезис та особливості реалізації національної програми Румунії “відкрий для себе ойну" у фізичному вихованні школярів. Вісник Прикарпатського університету. Серія: Фізична культура. 2019 Берез 26; 33: 114-119

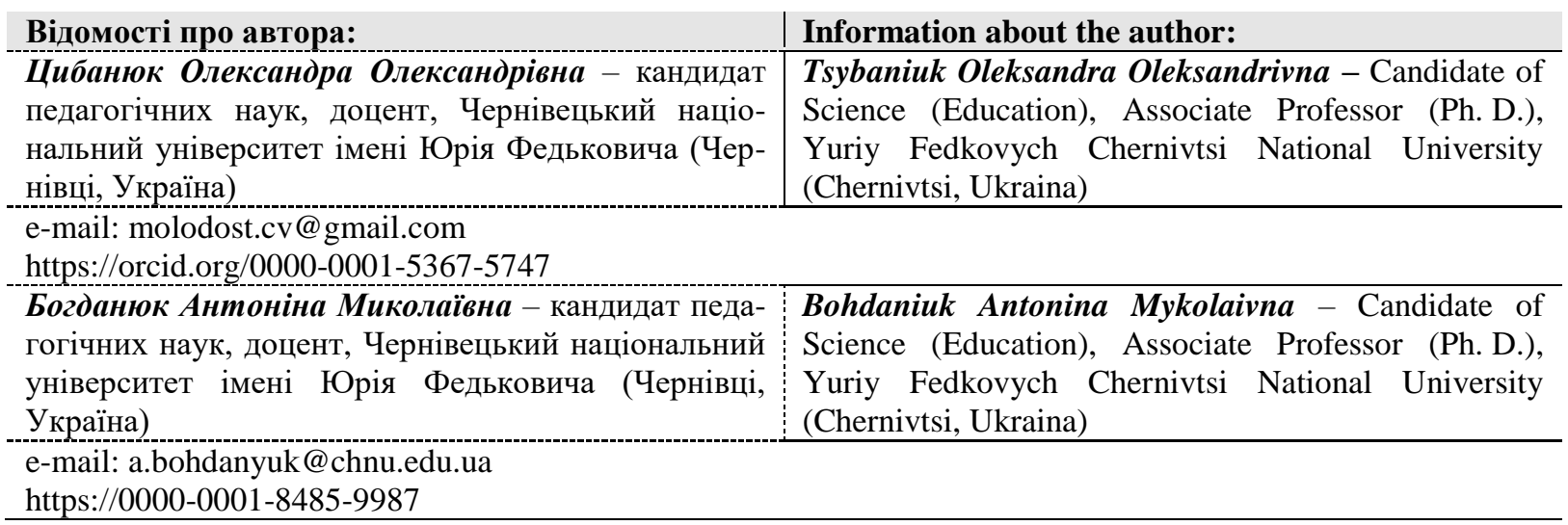

УДК 373.3.016: 792.8

doi: 10.15330/fcult.33.119-124

Наталія Чупрун

\section{УМОВИ ФОРМУВАННЯ КООРДИНАЦЙНИХ ЗДІБНОСТЕЙ МОЛОДШИХ ШКОЛЯРІВ ЗАСОБАМИ ХОРЕОРГАФІї}

Стаття присвячена вивченню проблеми формування координаційних здібностей у дітей молодшого шкільного віку засобами хореографії. Мета роботи - розкрити оптимальні педагогічні умови формування основних компонентів координаційних здібностей у дітей молодшого шкільного віку в процесі занять хореографією. Методи і організаиія дослідження: аналіз і узагальнення науково-методичной літератури та передової педагогічної практики, методи математичної статистики. Дослідження проводилося на базі ЗОШ №7 м. Переяслав-Хмельницький, в експерименті взяли участь 59 дівчаток $і 62$ хлопчики молодшого шкільного віку. В статті висвітлені оптимальні педагогічні умови для ефективного 